\title{
Gender and Environmental Management: Who's Role? Who's Responsibilities?
}

\author{
David Owino Manoa* \\ Department of Geography \& Environmental Studies, University of Nairobi, P.O. Box 30197, 00100, Nairobi, Kenya \\ *Corresponding author: davidmanoa@me.com
}

\begin{abstract}
Since the 1972 Conference on Human Environment in Sweden, the issue of gender has been discussed internationally in different fora. The discussions are in realisation of the role of gender in resources access, control and shaping the ecological processes. Although, the connection between gender and the environment is not obvious and direct, examining gender on the basis of: the roles and responsibilities; access and control; different knowledge; and decision making brings out the connections. This papers looks at gender from these prisms to discern both positive and negative effect of gender to environmental resource management.
\end{abstract}

Keywords: gender, environment, role, responsibilities, resources, management

Cite This Article: Manoa David Owino, "Gender and Environmental Management: Who's Role? Who's Responsibilities?” World Journal of Social Sciences and Humanities, vol. 3, no. 3 (2017): 61-63. doi: 10.12691/wjssh-3-3-2.

\section{Introduction}

The issue of gender and the environment was for the first time discussed during the 1972 Conference on Human Environment in Stockholm-Sweden [16].This was culminated with the formation of a gender policy the year 2000 to promote gender equity in participation in all development areas. The gender policy requires that all socio-economic policies, programmes, plans, projects and the national budget are gender-responsive [13].

The World Bank [16] defines gender as "a culturally based expectation of the roles and behaviours of males and females". [6] stresses that gender is a critical variable in shaping resource access and control, interacting with class, caste, race, culture and ethnicity to shape processes of ecological change. [6] further writes: "gender had a place in the struggle of men and women to sustain ecologically viable livelihoods, and the prospects of community for sustainable development”.

Environmental resources management has been described by [12] to includes all those activities which are designed to govern the use of lands, forest, water, air and mineral resources in given environment, taking into account environment conditions, social, economic and political implication, technological, national policy, and possible future needs.

[6] warns that, "the connection between gender and the environment is not always that simple, obvious and direct". However, [6] further explains that there is always some connection between the problems of gender and natural resources. As such, it becomes important to consider of the relation between gender relations and environment change as a two-way one.
The [17] therefore recommended that the nexus between gender and environment be approached by examining the following key factors: roles and responsibilities of men and women, access to and control over resources, knowledge of resources, and authority to make decision about resource use. Building on [17], this paper demonstrate how the gender roles can have both positive and negative effects in environmental management.

\section{Environmental Resources and Gender Roles}

Natural resources are exploited in most regions of the world for commercial purposes. However, it has been documented that men play a greater role than women in exploiting the natural resources. The exploitation can be in form of livestock grazing, logging, fishing, mining and various tree products [14].

[11] affirms that throughout the history men have looked at natural resources as commercial entities or income generating tool, while women tended to see the environment as a resource supporting their basic needs. [11] assertions are supported by a case study of women in rural areas of India who were observed to collect the dead tree branches cut by storm for fuel wood to use instead of cutting live trees. The rise of the environmental movement called 'Chipko movement' was initiated by Indian women who protested against loggers in their forest (the so called "tree huggers"). Their male counterparts are reported to have been diverted from their villages to a fictional payment compensation site while logging went on [8].

Other than women getting involved in economic activities like men, they have additional domestic responsibilities such as fuel wood and water collection, 
child care, family health maintenance, and food preparation. Domestic responsibilities for men are minimal compared to those of women [1]. Even the way the time is spend on various roles differs. For instance in a study conducted in Co te d' voire by [5], indicated that women worked both in and outside the home, while men worked almost exclusively outside home. Men engaged in harvesting and storing crops, fishing and gathering while women cooked, fetched firewood and water, and housekeeping.

A high rate of male migration from rural area to urban areas in search of employment has been found to exert work burden to women especially those with no older sons. For instance in Nepal, the migration of men was found to double the physical work burden with the traditionally male task such as ploughing remaining unattended to [4]. Based on this, the migration of men can be argued out that it does not only influence gender roles, but also affect the environment. For instance, food production may be limited resulting to food insecurity that may drive women to make use of the available natural resources for livelihood. The men who migrate to urban area also may not find sustaining jobs and hence resorting to live in informal settlements, also putting pressure on already scarce resources such water and sanitation services.

Although it is estimated that about $70 \%$ of the poor people in the world depend on land, water and forest for subsistence and income, the ability of women and men rights to own land and controls resources is constrained by the institutional, economic, legal and social constraints [5]. Citing forest ownership by the government in most part of the world, the World Bank report asserts that community lack secure access to and control over resources such as fuel wood, timber, and fauna for food for livelihood [15].

Women especially in developing world have limited access to land and even where they have legal rights, it is more on paper than in practice. Women lose their right to land when divorced or when their spouses passes on. Men control nearly all of the properties [7].

The insure land tenure determines how gender make use of the natural resources. The poor, women and the marginalised groups are less likely to invest time and resources or adopt environmentally sustainable farming practices on land they do not own. They opt to rent land, cultivate on steep slopes, use less resources to control soil erosion and move to already degraded areas [3]. All these will result to environmental destruction, through soil erosion, siltation of the rivers, soil salinization, food insecurity that eventually results to excessive use of natural resources for livelihood. On the other hand, the men who have a control over resources are more likely to plant trees for food, medicine, and invest more in the land.

Restriction on land rights also hinder access to other resources and information by women. As result women are not able to obtain loans, cannot hire labour to efficiently make use of their land, and have difficulty in adopting new technologies that embrace environmental protection such as recycling, green growth, reduction in $\mathrm{CO}_{2}$ emissions [16]. [3] adds that, many agricultural extension agents focuses their service to men, even where the women are the primary farmers. Although both men and women are exposed to environmental degradation, women and children have been observed to face greater adverse effects, particularly in rural areas and in urban informal settlements with inappropriate sanitary, water, and health facilities ([2]. Given the environmental degradation caused while men have dominance over women, steered some scholars such as [14] to hypothesise that "women would protect the Earth better than men if in power".

Gendered knowledge about sustainable resource management practices varies by class, age and ethnicity underscoring its complexity. For instance, a study [10] in Brazil found out that midwives were knowledgeable about certain plants which were different from those known by traditional medicine men. [9] claims that both men and women understand the ecological successions, habitats and life cycles of resources species. Therefore, understanding the different knowledge of women and men, old and young, boys and girls in different socio-economic circumstances greatly determines the type of sustainable interventions to protect the environment.

Despite several major United Nations conferences such as the Conference on Environment and Development (Rio de Janeiro, 1992) and Beijing women conference in 1995 having acknowledged the women's contributions to environmental management, women's involvement in environmental policy formulation, and execution remains low from the local, national and international levels [16] The lack of participation in decision making means that women's perspectives, needs, knowledge, and possible solutions are often ignored. Failure to include both men and women activities in decision making process can lead to defective policies that criminalizes the livelihood activities and undermine environmental protection practices by the communities [9].

\section{Conclusions}

The roles and responsibilities of both women and men affect the environment through their socio-economic activities and the resulting changes affects people's wellbeing. Often women's work is related to the natural environment and environmental conditions. Although men also perform several tasks, their time and energy inputs is substantially less than that of women. Hence one can speak of gender differentiation; environmental security being mediated by gender relations; and women and men have both conflicting and complementary interests and roles in environmental management. There are significant differences between women's and men's environmental change because of gender inequalities in access to environmental resources. Advancing gender equality, through reversing the various socio-economic handicaps that make women, men and marginalised groups voiceless and powerless, may be one of the best way of protecting the environment.

\section{References}

[1] Agarwal, B. (1997). "Environmental Action, Gender Equity and Women's Participation”, Development and Changes, 28: 1-39.

[2] Dankelman, I. (2002). Gender and Environment: Lesson to Learn. In Quality of Human Resources: Gender and indigenous people. Centre for Environmental Studies, University of Nijmegen, Netherlands. 
[3] Fortmann, L., Antinori, C., and Naban, N. (1997). Fruits of their labour: gender property rights and tree planting in two Zimbabwean villages. Rural Sociology 62 (3): 295-314.

[4] International Fund for Agricultural Development. (IFAD) (2001) Gender and Household Food Security. Available at: www.ifad.org/gender/learning/role/workload/24.htm Accessed on $25^{\text {th }}$ March 2015.

[5] Levine, J. A., Weisell, R., Chevassus, S., Martinez, C.D., Burlingame, B., and Coward, W.A. (2001). The Work Burden of Women. Science, 294: 812.

[6] Leach, M. (1991). Gender and the Environment: Traps and Opportunities. Paper prepared for Development Studies Association (DSA) conference, Swansea, September 11-13. Institute of Development Studies, Brighton.

[7] Mehra, R. (1995). Women, Land, and Sustainable Development, International Centre for Research on Women (ICRW). Working Paper, Vol. 1.

[8] Menon, G. (1991). Ecological transitions and the changing context of women's work in tribal India.

[9] Nancy, T. (2003). Passing on the News: Women's work, traditional knowledge and plant resources management in indigenous Societies of North-western North America. In: Howard, P. eds. (1999). Women \& Plants. Zed Books, London. PP. 133-149.
[10] Oliveira, R and Anderson, S. E. (1999). Gender, Conservation and Community participation: the Case of Jau National Park, Brazil. Florida, University of Florida.

[11] Radda, A. (1991). Women and Environment. New Jersey. Zed Book Ltd

[12] Shettima, A.G. (1996). Gender Issues in Monitoring the Environment: The case of Rural Nigeria. A paper presented at the 39th Annual conference of the Nigerian Geographical Association, 5th - 8th May, at University of Maiduguri.

[13] United Nations Human Settlement Programme (UN-Habitat) and Gender and Water Alliance (GWA). (2005). Navigating Gender in Africa Cities: Synthesis Report of rapid Gender \& Pro-poor Assessment in 17 African Cities.

[14] Wenz, P.S. (2001). Environmental Ethics Today. New York, Oxford university press

[15] World Bank. (2000). World Development Report 2000-2001. Washington, DC.

[16] World Bank. (2002). Integrating Gender into the World Bank's Work: A Strategy for Action.

[17] Population Reference Bureau (2002). WOMEN, MEN, AND ENVIRONMENTAL CHANGE: The Gender Dimensions of Environmental Policies and Programs. 1875 Connecticut Ave., NW, Suite 520, Washington, DC 20009 USA. 